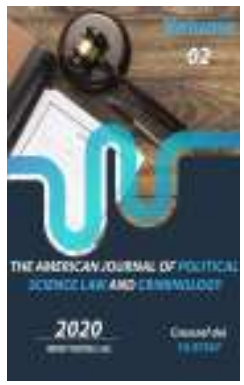

Journal Website: http://usajournalshub.c om/index,php/tajpslc

Copyright: Original content from this work may be used under the terms of the creative commons attributes 4.0 licence.

\section{Developing Critical Thinking Ability In Students On The Basis Of Problem Approach (On The Example Of The Subject "Civil Society")}

\author{
Kudayberganova Tajixal Kuchkarovna \\ Republic Of Uzbekistan, Associate Professor Of Nukus State Pedagogical Institute Named After \\ Ajiniyaz, Candidate Of Pedagogical Sciences, Uzbekistan \\ Tileyov Erkinbay Muratbayevich \\ Senior Lecturer, Doctor Of Philosophy In Pedagogical Sciences, Nukus State Pedagogical \\ Institute Named After Ajiniyaz, Republic Of Uzbekistan
}

\title{
ABSTRACT
}

This article discusses the development of students' critical thinking skills and its consequences on the basis of a problem-based approach on the example of the subject "Civil Society" in the universities of the Republic of Uzbekistan.

\section{KEYWORDS}

Information by an individual, source of the information disseminated

\section{INTRODUCTION}

In recent years, due to the rapid development of science, engineering, technology and production, the demand for qualified specialists has increased dramatically. Today, along with the qualities of professional competence, a specialist has a tradition of creative, creative and critical thinking, which determines the level of his qualification. In determining the professional competence of a specialist, pedagogical creative thinking means finding creative solutions to professional problems, creative thinking means working in the process of solving professional problems based on advanced, modern approaches, while critical thinking means evaluating and analyzing the situation in different positions. means. Critical thinking is a type of thinking that promotes a non-standard approach to any idea and provides for the ever-changing flow of information. This type of thinking allows an 
individual to develop the ability to process and organize information, express themselves quickly and accurately, as well as learn independently and collaborate with others in a practical way.

This means that critical thinking avoids a onesided assessment of the situation, to analyze it comprehensively, to see the positive and negative effects, to use the positive effects effectively, and to eliminate the negative factors, to substantiate the decision and make it firm (correct, reasonable).

Critical thinking is the ability of an individual to create and explore alternatives, to define and examine perspectives; the ability to make a firm decision in understanding the problem and find a quick solution to it; ability to make well-thought-out and independent decisions; demonstrates qualities such as the ability to ask well-thought-out and clear questions.

\section{MATERIALS AND METHODS}

According to D. Cluster, critical thinking has the following five characteristics: first, independent thinking; second, possessing a mindset that allows for generalization; third, to demonstrate the ability to solve and evaluate problem situations; fourth, to be able to present evidence in making statements; fifth, to have a social mindset.

In the current situation where ideological struggles are in full swing, it is important for a person to have a critical mind. A person with such a mindset does not directly accept any information transmitted (disseminated) by electronic and print media. Rather, it studies it analytically. That is, it analyzes the essence of the main idea put forward in the information, what subjects it is aimed at, the social significance of the information - the impact on the development of the individual or society, the positive or negative impact on the development of events. By its very nature, the effort to study the content of information organized by an individual is a step-by-step process.

The study of the reliability of information by an individual takes place in several stages. They are: 1) an assessment of the importance of the idea in the information for the person (thinking about how useful, important and necessary this information is for the person); the source of the information disseminated - an interest in the reliability of the media; determine what other sources of relevant information are covered; to study the attitude of different sources to the coverage of relevant information; use relevant information in practice (including daily and professional activities).

The study of information on the basis of critical, comprehensive and in-depth analysis protects a person's life, health and psyche from its negative consequences. Consequently, in the current context of widespread ideological struggles, the main purpose of sources that disseminate destructive, negative information is to manipulate the individual, to control his desires and aspirations, to weaken his will, his character. Therefore, at various stages of the system of continuing education of the republic, especially in general secondary, secondary special and higher education institutions, it is necessary to teach the individual to think critically, to pay serious attention to the formation of critical thinking. The full satisfaction of this demand creates an opportunity to meet the social need of society, which consists in educating people who are independent, free-thinking, have their own views and life position. Therefore, educational institutions are faced with the pedagogical task of developing critical thinking in students. 
The period of building a civil society and the rule of law has begun in the history of Uzbekistan. Large-scale reforms are being carried out to ensure human rights and freedoms, further liberalize all spheres of public life. Important tasks are being carried out to develop the country innovatively, strengthen active citizenship and initiative in people, form an independent worldview and thinking skills, ensure the priority of justice in society, strengthen the rule of law, fight corruption and fight against ignorance and enlightenment.

It is obvious that as a result of the declaration of civil society as a strategic goal in the country, new urgent tasks have emerged. Study of the experience of countries in building civil society,

Democratization of national elements of civil society formed in the history of our country and their harmonization with foreign experience is a requirement of the time. It should be noted that the activity of civil society institutions in all spheres of public life is growing. The most important task in this area is to train personnel who can meet modern requirements to direct the activities of civil society institutions to the development of social, economic and cultural spheres. Therefore, the inculcation of theoretical and practical knowledge of civil society in the minds of students who are active participants in the construction of this society in the future is an important factor in determining the future and prospects of the country. As a result, teaching the subject of "Civil Society" as a subject in higher education has become an important necessity. Indeed, at a time of urgent reforms in the state and society, one of the most important tasks in education, especially in higher education, is to create conditions for young people to actively participate in this process and enrich their worldviews with theories of civil society building.

\section{RESULTS AND DISCUSSION}

The subject of "Civil Society" provides knowledge about the construction of civil society and its prospects, based on the tasks set by the current process of deepening the search for further development of the reform period. In the process of teaching this subject, the experience of building civil society in developed countries will be studied, with which changes in the results of reforms in the country will be compared.

It is planned to teach the subject "Civil Society" in the bachelor's degree of higher education. The main focus of teaching this subject is on the free thinking of students, the formation of their independent attitude to changes in society.

The purpose of teaching science is to teach students about the reforms in the formation and development of civil society, the essence of the strategy for their implementation, the relationship of man, state and society in civil society, the basic principles of democratization and modernization, the peculiarities of Uzbekistan in the formation and development of civil society through the formation of an active civic position and responsibility in them through in-depth knowledge. One of the main goals of science is to raise the patriotic feelings of young people, to increase their loyalty to the country, to educate them as people who are not indifferent to building a new society $\{8\}$.

The task of science is to study the subject, object, goals and objectives of the science of civil society, to analyze the ideas, directions and theories about civil society; to give an idea of the main features and mechanisms of interaction of the rule of law and civil society, the socio-political, legal and spiritual 
foundations of civil society; coverage of the "Uzbek model" of development and the scientific and methodological basis for building civil society, explanation of the essence of the "Strategy of Actions for the further development of the Republic of Uzbekistan for 2017-2021"; enriching students 'perceptions of the activities of citizens' self-government bodies, public control and ensuring the transparency of the activities of state bodies $\{9\}$.

The following requirements are set for the knowledge, skills and abilities of students in the subject. Student:

- Changes in the formation and development of civil society at a new stage of national development of Uzbekistan, the main directions of the "Action Strategy" for further development of the Republic of Uzbekistan, the foundations of civil society, scientific and methodological bases of civil society, citizenship, civil society institutions, suffrage , non-governmental organizations, social partnership, public-private partnership, public control and transparency of government agencies, "Human interests take precedence", "People should serve our people, not government agencies", "People are rich" to know the essence of the conceptual ideas such as "the state will be rich and powerful", the main directions and tasks set out in the "Action Strategy" for the further development of the Republic of Uzbekistan. be able to think, make proposals for further improvement of reforms in the formation and development of civil society in the new stage of national development of Uzbekistan, be able to analyze the achievements of our country and their international recognition. Therefore, the development of critical thinking skills in students on the basis of a problem-based approach in the subject of "Civil Society" is an urgent issue.
The following areas are taken into account in the development of students' critical thinking skills on the basis of a problem-based approach on the example of the subject "Civil Society": a competent approach to the teaching process; creation of educational and methodical support based on problem-based educational technologies; increase their learning activity based on the development of students' ability to think independently and critically.

Independent scientific research on the development of critical thinking skills in Uzbekistan has not been conducted on a large scale. F.Arabova, F. Berdieva, F.O. Khodjieva studied the issues of teaching critical thinking in primary, secondary and high school students of general secondary schools. The study of the problem was carried out by F.O. Khodjieva as an independent study, and the results of scientific research were published as a monograph, while F. Arabova, F. It has not been studied by Berdievas as a holistic study.

In the CIS countries, the problem of developing critical thinking skills in people of different ages has been widely studied as an independent study. In particular, A.S.Bayramov, N.A.Balashova, N.M.Vostrikova, N.V.Gunko, E.A.Degtyareva I.O.Zagashev, S.I. Zair-Bek, M.Kirilenko, N.V.Kozlova, E.Koxanova, N.A.Menchinskaya, S.Mirseitova, S.L.Rubinshteyn, S.N.Sadykova, L.Spirgene, S.A. In the works of such researchers as Filonenko, SV Stolbunova, BM Teplov, M.S. Shcheglova from a psychological and pedagogical point of view, the formation of critical thinking skills in students of primary and secondary schools, students of primary and secondary schools, the gradual development, methods and tools for developing critical thinking skills in the individual are analyzed.

The problem of developing the ability to think critically in the individual in developed foreign 
countries began to be studied in the 1920 s. Today, developed countries have a great deal of experience in studying this problem, and the knowledge imparted at all stages of the education system is based on encouraging students to think critically about information. Peter A. Facionet (Peter A. Fasioun), Noreen C. Facione (Norin K. Fasioun), David Kluster (David Cluster), Anthony Manzo (Anthony Manzo), Scott Plaus (Scott Plaus), Richard U. Research by Paul (Richard W. Paul), Diana Halpern (Diana Halpern), diagnostic assessment to determine the priority principles, guiding ideas, academic support, mechanism, methodology, as well as the level of critical thinking skills of the individual at different ages views on the justification of the criteria.

However, in the context of Uzbekistan, the problem is almost unexplored, in the current context of global information and ideological struggles, there is a socio-pedagogical need to accustom students to critical thinking at all stages of the continuing education system.

The aim is to study the ways of developing critical thinking skills in students on the basis of the problem approach in the example of the subject "Civil Society", which not only increases the effectiveness of the lesson, but also covers the theoretical and methodological bases of developing critical thinking skills in students. Priorities for the development of critical thinking are identified, the main stages are identified, the current state of development of critical thinking in students is assessed, the experience of foreign countries in the development of critical thinking in students is studied, organizational forms, effective methods, tools and technologies, mechanisms, criteria and levels are illuminated and the expected result is obtained.
During the implementation of this task, the following tasks will be solved:

1. The activities of the university are studied together with students. First of all, the level of development of critical thinking skills in students is assessed through the organization of questionnaires, questions and answers, conversations and interviews among teachers and students of higher education institutions. In addition to the study of pedagogical, psychological and methodological literature and documents of the educational institution, the use of a number of methods is also effective. They are: theoretical analysis; questionnaire, interview, interview; "Trial and error method" (or "Option selection method"), "Synectics" methods, "Random associations", etc.

2. As a result of problem-based teaching of the subject "Civil Society" the following tasks are performed:

1) Based on the problem-based approach, students develop the ability to think critically; At the new stage of national development of Uzbekistan can make proposals for further improvement of reforms in the process of formation and development of civil society;

2) Patriotic feelings increase in young people, their loyalty to the country increases, they are formed as a person who is not indifferent to building a new society;

3) Teachers of the university on the subject "Civil Society" will have effective didactic developments in teaching the subject;

4) Problem-based learning creates the necessary pedagogical conditions for students to master the subject "Civil Society". 


\section{REFERENCES}

1. Mirziyoev Sh.M. The rule of law and the protection of human interests are the key to the development of the country and the well-being of the people. - T .: "Uzbekistan" publishing house, 2017. - $9 \mathrm{p}$.

2. Decree of the President of the Republic of Uzbekistan "On radical improvement of the system of raising legal awareness and legal culture in society" (January 9, 2019) // http: //www.lex.uz/docs/4149765? Query = 20 Ministers of the Republic of Uzbekistan2.

3. Innovative educational technologies / Muslimov NA, Usmonbaeva MH, Sayfurov DM, Turaev AB - T :: "Sano-standart" publishing house, 2015. - 150 pages.

4. Social organizations, social organizations in Uzbekistan //https://uz.ellowpages.uz/rubrika/ social organizations? Pagenumber $=2$ \& pagesize $=$

5. Mazurenko A.V. Pedagogicheskie usloviya stanovleniya i razvitiya sotsialnyx kachestv studentcheskoy molodyoji $\mathrm{v}$ kulturnoobrazovatelnoy srede vuza: diss ... kand.ped.nauk. - Rostov-on-Don: 2006. - p. 86.

6. Suslov A.B. Development of civic education in the experience of European countries //https://cyberleninka.ru/article/n/opytrazvitiya-grazhdanskogo-obrazovaniya-vevropeyskih-stranah

7. Regulations on the organization, control and evaluation of independent work of students // http: //library.tma.uz/uum2/uum-omh-

epidemiology/02-general part / 2\% 20Fan\% 20\% 20independent\% 20ish\% 20State / Student\% 20Independent\% 20work\% 20Organization\% 20Achievement\% 20Student.pdf
8. Fundamentals of Civil Society: Textbook / A. Jalilov, U.Muhammadiev, Q. Juraev et al. - Tashkent, 2015, 264 p.

9. "Development strategy of Uzbekistan. Civil Society "science program, National University, 2018. 